\title{
CULTURE SYSTEM AND LONG-TERM STORAGE OF CULTURE MEDIA IN THE IN VITRO PRODUCTION OF BOVINE EMBRYOS
}

\author{
Santiago de la VARGA ${ }^{1}$, Carmen DIEZ ${ }^{2}$, Lina FERNÁNDEZ ${ }^{1}$, Jenny ÁLVAREZ ${ }^{1}$, \\ Adelino Katchicualula ${ }^{1}$, Carlos Olegario Hidalgo ${ }^{2}$, Carolina TAMARGO ${ }^{2}$ \\ and Maite CARBAJO ${ }^{1 *}$ \\ ${ }^{1}$ Department of Animal Reproduction and Obstetrics, Faculty of Veterinary Medicine, \\ University of León, Campus de Vegazana s/n., 24071 León, Spain; ${ }^{2}$ Servicio Regional de \\ Investigación y Desarrollo Agroalimentario (SERIDA), Gijón, Spain
}

(Received 2 June 2009; accepted 7 October 2010)

The optimum culture system for in vitro matured and fertilised oocytes still remains to be clarified. Culture media (CM) for mammalian embryos are routinely prepared fresh for use and preserved under refrigeration during one or two weeks. The purposes of this work were (1) to compare the efficiency of a synthetic oviduct fluid (SOF) with two different bovine serum albumin (BSA) concentrations ( 3 and $8 \mathrm{~g} / \mathrm{L}$ ) for the in vitro production of bovine blastocysts, (2) to test the effect of timing on adding fetal calf serum (FCS) to the SOF, and (3) to evaluate the effects on bovine embryo development of freezing and lyophilisation as procedures for preserving the SOF. Supplementation of SOF with $3 \mathrm{~g} / \mathrm{L}$ BSA increased Day-7 blastocyst expansion rates $(18.3 \pm 1.6$ vs. $14.4 \pm 0.7 ; \mathrm{P}<0.05)$, although no differences in hatching rates were found. Addition of FCS to SOFaa (SOF with amino acids) medium supplemented with sodium citrate (SOFaaci) at 48 and at $72 \mathrm{~h}$ post-insemination (PI) allowed obtaining higher Day- 6 embryo development rates than when FCS was added at 18 or $96 \mathrm{~h}$ PI (Day-6 morulae + blastocyst rate: $30.0 \pm 1.1,40.8 \pm 1.1,43.9 \pm 2.3$ and $39.3 \pm 0.5$ for FCS addition at $18,48,72$ and $96 \mathrm{~h}$, respectively). Hatching rates were significantly improved when serum was added at $72 \mathrm{~h}$ PI. Finally, both refrigeration and lyophilisation appeared as useful cryopreservation procedures for SOFaaci, although a significant loss of its ability to support embryo development, compared to the control fresh culture medium, was observed.

Key words: Culture medium, FCS, SOF, media storage, bovine embryos

Mammalian preimplantation embryos normally develop within the environment of the female reproductive tract. In the cattle embryo transfer industry, embryos are increasingly produced totally in vitro from immature oocytes collected by ovum pick-up (OPU) or from slaughterhouse ovaries. Oocytes are then

*Corresponding author; E-mail: mtcarr@unileon.es; Phone: 0034 (98) 729-1321; Fax: 0034 (98) 729-1269 
matured, fertilised and cultured in vitro up to the blastocyst stage. Modification of the culture conditions, particularly in the post-fertilisation culture, can significantly impact the quality of the resulting blastocysts; however, really significant improvements in the yield of blastocysts can be achieved only by improving the quality of the oocyte subjected to in vitro maturation (IVM) (Lonergan et al., 2003). Despite the efficiency of in vitro production systems in yielding considerable numbers of embryos, the major fall-off in in vitro embryo development occurs between the two-cell and blastocyst stages, supporting the hypothesis that post-fertilisation embryo culture is the most critical period of the process in terms of determining blastocyst quality (Lonergan et al., 2003).

Simplifications of in vitro culture conditions have been considered and several media for producing bovine embryos in vitro have been developed. The embryos show their plasticity by adapting their developmental traits to the environmental conditions, being able to grow up under different conditions. The ability of embryos to develop in a particular medium does not necessarily indicate a beneficial or preferable environment but may instead simply reflect their ability to tolerate these artificial conditions. However, this degree of adaptation to environmental conditions and/or the rate of adaptation to changing conditions will also result in a certain degree of biochemical stress on the embryo (Lonergan, 2007).

Almost all media used for embryo development contain serum or bovine serum albumin (BSA) as a protein source. Several authors have demonstrated the favourable effects of BSA on embryo development and in the in vitro survival of bovine blastocysts to vitrification (Gómez et al., 2008). The role of serum is not completely clear, although serum is known to provide energy substrates, amino acids, vitamins, growth factors and heavy-metal chelators (Pinyopummintr and Bavister, 1994). Although embryo culture in media supplemented with serum allows obtaining a higher development rate to the blastocyst stage, it has been largely demonstrated that the presence of serum during embryo culture causes alterations in the ultrastructure of embryos, impaired compaction, abnormal blastulation, large calf syndrome, aberrant mRNA expression profiles, and greater incidences of stillbirths and deaths after birth (Van Langendonckt et al., 1997; Holm et al., 1999; Abe et al., 2002; Wrenzycki et al., 2004). Moreover, bovinederived sera or proteins have recently been avoided especially in human IVP systems because of the appearance of bovine spongiform encephalopathy and a viral or prion contamination risk. Consequently, the optimum culture system for the in vitro production of bovine embryos still needs to be clarified.

Culture media (CM) for mammalian embryos are routinely prepared fresh for use, and preserved under refrigeration during one or two weeks (de la Varga et al., 2005). This fact implies a consumption of time in the laboratory and introduces variability in the manipulations. An adequate preservation system could reduce the time of manipulation and increase the reliability of the experiments. 
Freezing and stocking ready-to-use media for IVP including protein supplementation may result in considerable advancement towards rationalisation, cost reduction and reliability of the experiments. The labile nature of biological products affects long-term storage. Other factors affecting the stability of media are microorganisms, humidity, enzymes, oxygen and temperature changes (de la Varga et al., 2005).

Refrigeration and freezing represent physical means for preservation, since they regulate a lowering of the temperature, which not only slows or prevents the development of microorganisms that might modify reagents, but also paralyses the activity of enzymes (Prescott et al., 2009). The lyophilisation approach is used in all cases when the quality of samples would be damaged if the standard or any other method were used for drying.

Consequently, the aim of this work was: (1) to compare the efficiency of two BSA concentrations added to a synthetic CM (synthetic oviduct fluid; SOF) for the in vitro production of bovine blastocysts, (2) to test the effect of adding fetal calf serum (FCS) to the SOF at different periods of the embryo culture, and (3) to evaluate freezing and lyophilisation as procedures for preserving the SOF, and their subsequent effects on further bovine embryo development.

\section{Materials and methods}

Except otherwise indicated, all reagents were purchased from Sigma (Madrid, Spain). Culture media were prepared with Milli Q water, grade I.

\section{Oocyte recovery}

Ovaries recovered from slaughtered cows were placed in $\mathrm{NaCl}$ solution $(9 \mathrm{mg} / \mathrm{mL})$ containing antibiotics (penicillin, $100 \mathrm{UI} / \mathrm{mL}$ and streptomycin sulphate, $100 \mu \mathrm{g} / \mathrm{mL}$ ) and maintained at $30^{\circ} \mathrm{C}$ until recovery of cumulus-oocyte complexes (COCs). Ovaries were washed twice in distilled water and once in freshly prepared saline. The COCs were aspirated from 2- to 7-mm visible follicles through an 18-gauge needle connected to a syringe, and recovered in a $50-\mathrm{mL}$ Corning tube. Follicular fluid and COCs were placed in an ovum concentrator (Em-Con, Comextrade, Spain) and rinsed 3 times with holding medium (HM: TCM199 + $25 \mathrm{mM}$ Hepes + BSA 0.4 g/L) supplemented with $2 \mathrm{IU} / \mathrm{mL}$ of heparin.

\section{In vitro maturation}

Only oocytes enclosed in a compact cumulus with evenly granulated cytoplasm were selected for maturation. The COCs were washed 3 times in HM and twice in maturation medium, which consisted of TCM199, $\mathrm{HNaCO}_{3}(2.2 \mathrm{~g} / \mathrm{L})$, fetal calf serum (FCS, 10\% v:v), FSHp $(1 \mu \mathrm{g} / \mathrm{mL})$, LH $(5 \mu \mathrm{g} / \mathrm{mL}), 17 \beta$-oestradiol 
$(1 \mu \mathrm{g} / \mathrm{mL})$ and cysteamine $(100 \mu \mathrm{M})$. Maturation was performed by culturing approximately $50 \mathrm{COCs}$ in $500 \mu \mathrm{L}$ of maturation medium in four-well dishes at $39{ }^{\circ} \mathrm{C}$ in $5 \% \mathrm{CO}_{2}$ in air and high humidity.

\section{In vitro fertilisation}

Sperm separation was carried out using a swim-up procedure similar to that reported by Parrish et al. (1986). Briefly, semen from 1 frozen straw of a single bull was thawed in a water bath and added to a polystyrene tube containing $1 \mathrm{~mL}$ of pre-equilibrated Sperm-TALP. After $1 \mathrm{~h}$ of incubation, the upper layer of supernatant containing the motile sperm was removed. The spermatozoa were centrifuged for $7 \mathrm{~min}$ at $100 \times g$ and the supernatant aspirated to leave a pellet of approximately $100 \mu \mathrm{L}$ in volume. Sperm concentration was determined with a haemocytometer. After 22 to $24 \mathrm{~h}$ of maturation, COCs were washed 2 times in $\mathrm{HM}$ and placed in four-well culture dishes containing pre-equilibrated fertilisation medium (Fert-TALP) with heparin $(10 \mu \mathrm{g} / \mathrm{mL})$. Spermatozoa were then added at a concentration of $2 \times 10^{6}$ cells $/ \mathrm{mL}$ in $500 \mu \mathrm{L}$ of medium per well containing a maximum of 100 COCs. In vitro fertilisation (IVF) was accomplished by incubating gametes for 18 to $20 \mathrm{~h}$ at $39{ }^{\circ} \mathrm{C}$ in $5 \% \mathrm{CO}_{2}$ and high humidity.

\section{In vitro culture}

Presumptive zygotes were vortexed for 2 min to separate cumulus cells, washed 3 times in HM and twice in the CM before putting them in $50-\mu \mathrm{L}$ droplets of CM that were prepared in four-well dishes under mineral oil and equilibrated for $2 \mathrm{~h}$ before addition of zygotes. Embryo culture (25-40 embryos/drop) was performed at $39{ }^{\circ} \mathrm{C}$ under $5 \% \mathrm{CO}_{2}$ in air. Culture media were renewed on days 3 and 6. Embryo development was analysed on days 3 and 6 to 9 .

\section{Experimental design}

In the first experiment, we compared the efficiency of two BSA concentrations added to the synthetic oviduct fluid (SOF) developed by Takahashi and First (1992). Thus, presumptive zygotes were randomly assigned to one of two culture systems. In Group SOF-T3 the zygotes were cultured in SOF supplemented with $3 \mathrm{~g} / \mathrm{L}$ of BSA. In Group SOF-T8, zygotes were cultured in SOF supplemented with $8 \mathrm{~g} / \mathrm{L}$ of BSA (SOF-T8). In both groups, $5 \%$ of FCS was added to the $\mathrm{CM}$ at $42 \mathrm{~h}$ PI.

In the second experiment, we tested the effect of adding FCS to SOF with amino acids medium supplemented with sodium citrate (SOFaaci) (Holm et al., 1999) at different times of the culture period on blastocyst production and hatching rates. Thus, the development ability of bovine embryos cultured in SOFaaci after the addition of $5 \%$ of FCS at 18 h PI (Group 18 h), 48 h PI (Group 48 h), $72 \mathrm{~h}$ PI (Group $72 \mathrm{~h}$ ) and $96 \mathrm{~h}$ PI (Group 96 h) was tested. 
Finally, in a third experiment, we analysed two long-term preservation procedures for the CM, and the consequences of its use on the ability of SOFaaci to support embryo development. Thus, we analysed embryo development of bovine zygotes cultured in: fresh SOFaaci (control; Group CTRL) (Holm et al., 1999), frozenthawed SOFaaci (Group F-T), and lyophilised-reconstituted SOFaaci (Group LYO).

In Group F-T, SOFaaci was frozen at $-20{ }^{\circ} \mathrm{C}$ and thawed at room temperature.

For the lyophilisation, SOFaaci was frozen for $3 \mathrm{~h}$ at $-48{ }^{\circ} \mathrm{C}$, then transferred to the freeze-dryer (TELSTAR-LIOALFA 10, Spain) and processed according to an eight-step cycle: (1) First drying $-48^{\circ} \mathrm{C}$ and $0.5 \mathrm{mbar}$ for $1 \mathrm{~h}$; (2) $40{ }^{\circ} \mathrm{C}$ and $0.2 \mathrm{mbar}$ for $2 \mathrm{~h}$; (3) $-30{ }^{\circ} \mathrm{C}$ and 0.2 mbar for $2 \mathrm{~h}$; (4) $-20^{\circ} \mathrm{C}$ and $0.2 \mathrm{mbar}$ for $2 \mathrm{~h}$; (5) $-10{ }^{\circ} \mathrm{C}$ and $0.2 \mathrm{mbar}$ for $2 \mathrm{~h} ;(6)-5^{\circ} \mathrm{C}$ and $0.2 \mathrm{mbar}$ for $2 \mathrm{~h}$; (7) Second drying: $5{ }^{\circ} \mathrm{C}$ for $3 \mathrm{~h}$; (8) $15^{\circ} \mathrm{C}$ for $6 \mathrm{~h}$. The lyophilised SOFaaci was rehydrated by adding milliQ sterile water and matched to the osmotic pressure (270-280 mOsm/Kg).

In each replicate of this experiment, both frozen-thawed and lyophilised media were obtained from the same lot of fresh medium that was used as control.

\section{Statistical analysis}

Data were analysed by ANOVA and Duncan's test $(\mathrm{P}<0.05)$, by means of SAS (Version 8.2, 1999, SAS Institute Inc, Cary Inc.) and expressed as mean \pm standard error. Embryo development rates were corrected for cleavage data and expressed referred to this value.

\section{Results}

A total of 3640 oocytes were subjected to IVM and IVF, and used for the three experiments.

In Experiment 1 (Table 1), the addition of $8 \mathrm{~g} / \mathrm{L}$ BSA increased the cleavage rates on Day 3, although the 5-8 cell percentages were higher in the SOF-T3 compared to the SOF-T8 group. Day-6 development was similar between the groups; however, SOF-T3 increased the Day-7 expansion rates. No differences were found in hatching rates between the two CM.

In the second experiment (Table 2), embryo development between Days 3 and 8 was significantly affected by the time of addition of FCS to the CM. Although developmental rates on days 3 and 6 were similar in Group $48 \mathrm{~h}$ and Group $72 \mathrm{~h}$, the best results in terms of hatching rates were obtained when FCS was added at $72 \mathrm{~h}$ PI.

Both the freezing-thawing and the lyophilisation procedures affected the ability of the SOFaaci to support embryo development up to the hatching stage (Table 3). Thus, embryos belonging to the F-T and LYO groups developed at lower rates than those cultured in the control group. 


\section{Table 1}

Embryo development of bovine zygotes cultured in SOF-T (Takahashi and First, 1992) supplemented with $3 \mathrm{~g} / \mathrm{L}$ (SOF-T3) or with $8 \mathrm{~g} / \mathrm{L}$ (SOF-T8) of BSA

\begin{tabular}{|c|c|c|c|c|c|c|c|}
\hline \multirow{2}{*}{ Group } & \multirow{2}{*}{$\mathrm{N}$} & \multicolumn{2}{|c|}{ Day 3} & \multicolumn{2}{|c|}{ Day 6} & \multirow{2}{*}{$\frac{\text { Day } 7}{\% \operatorname{Exp}}$} & \multirow{2}{*}{$\begin{array}{c}\text { Day } 9 \\
\% \text { Hatch }\end{array}$} \\
\hline & & $\%$ Cleaved & $\% 5-8 c$ & $\% M+B$ & $\% \mathrm{~B}$ & & \\
\hline SOF-T3 & 292 & $52.5 \pm 0.9^{\mathrm{a}}$ & $48.4 \pm 2.9^{\mathrm{a}}$ & $44.5 \pm 3.4$ & $16.9 \pm 1.89$ & $18.3 \pm 1.6^{\mathrm{a}}$ & $8.5 \pm 1.5$ \\
\hline SOF-T8 & 289 & $65.0 \pm 0.6^{b}$ & $38.9 \pm 0.7^{b}$ & $39.5 \pm 1.1$ & $15.5 \pm 1.40$ & $14.4 \pm 0.7^{\mathrm{b}}$ & $5.8 \pm 0.9$ \\
\hline
\end{tabular}

M: morulae; B: blastocysts; Exp: Expanded blastocysts; Hatch: Hatched blastocysts; data (6 replicates) are $\mathrm{LSM} \pm \mathrm{SE}$. Different superscripts within columns differ statistically significantly $\left({ }^{\mathrm{a}, \mathrm{b}} \mathrm{P}<\right.$ 0.05). Cleavage rates are referred to the zygotes cultured. Embryo development from Day 3 to Day 9 is referred to cleaved embryos

\section{Table 2}

Embryo development of bovine zygotes cultured in SOFaaci (Holm et al., 1999) after the addition of $5 \%$ of FCS at $18 \mathrm{~h}$ (Group $18 \mathrm{~h}$ ), $48 \mathrm{~h}$ (Group 48 h), $72 \mathrm{~h}$ (Group $72 \mathrm{~h}$ ) and $96 \mathrm{~h}$ (Group $96 \mathrm{~h}$ ) post-insemination

\begin{tabular}{|c|c|c|c|c|c|c|c|}
\hline \multirow{2}{*}{ Group } & \multirow{2}{*}{$\mathrm{N}$} & \multicolumn{2}{|c|}{ Day 3} & \multicolumn{2}{|c|}{ Day 6} & \multirow{2}{*}{$\frac{\text { Day } 7}{\% \operatorname{Exp}}$} & \multirow{2}{*}{$\begin{array}{c}\text { Day } 9 \\
\% \text { Hatch }\end{array}$} \\
\hline & & $\%$ Cleaved & $\% 5-8 \mathrm{c}$ & $\% M+B$ & $\% \mathrm{~B}$ & & \\
\hline $18 \mathrm{~h}$ & 292 & $70.6 \pm 0.8^{\mathrm{ab}}$ & $32.9 \pm 1.3^{b}$ & $30.0 \pm 1.1^{\mathrm{c}}$ & $14.0 \pm 0.9^{b}$ & $26.1 \pm 2.1^{b}$ & $9.2 \pm 0.4^{\mathrm{c}}$ \\
\hline $48 \mathrm{~h}$ & 289 & $68.5 \pm 0.4^{\mathrm{c}}$ & $42.4 \pm 0.8^{\mathrm{a}}$ & $40.8 \pm 1.1^{\mathrm{ab}}$ & $18.1 \pm 1.5^{\mathrm{ab}}$ & $27.6 \pm 1.9^{\mathrm{ab}}$ & $12.5 \pm 1.7^{\mathrm{c}}$ \\
\hline $72 \mathrm{~h}$ & 296 & $72.1 \pm 0.7^{\mathrm{a}}$ & $46.2 \pm 1.7^{\mathrm{a}}$ & $43.9 \pm 2.3^{\mathrm{a}}$ & $19.7 \pm 1.8^{\mathrm{a}}$ & $32.9 \pm 3.2^{\mathrm{a}}$ & $25.9 \pm 2.3^{\mathrm{a}}$ \\
\hline $96 \mathrm{~h}$ & 319 & $70.2 \pm 0.4^{\mathrm{bc}}$ & $45.9 \pm 1.2^{\mathrm{a}}$ & $39.3 \pm 0.5^{\mathrm{b}}$ & $16.9 \pm 0.9^{\mathrm{ab}}$ & $24.9 \pm 0.9^{b}$ & $17.9 \pm 1.3^{b}$ \\
\hline
\end{tabular}

M: morulae; B: blastocysts; Exp: Expanded blastocysts; Hatch: Hatched blastocysts; data (6 replicates) are $\mathrm{LSM} \pm \mathrm{SE}$ data. Different superscripts within columns differ statistically significantly $\left({ }^{\mathrm{a}, \mathrm{b}, \mathrm{c}} \mathrm{P}<0.05\right)$. Cleavage rates are referred to the zygotes cultured. Embryo development from Day 3 to Day 9 is referred to cleaved embryos

\section{Table 3}

Embryo development of bovine zygotes cultured in fresh SOFaaci (control; Group CTRL) (Holm et al., 1999), or in the same medium frozen-thawed (Group F-T), or lyophilised-reconstituted (Group LYO)

\begin{tabular}{|c|c|c|c|c|c|c|c|}
\hline \multirow{2}{*}{ Group } & \multirow{2}{*}{$\mathrm{N}$} & \multicolumn{2}{|c|}{ Day 3} & \multicolumn{2}{|c|}{ Day 6} & \multirow{2}{*}{$\begin{array}{l}\text { Day } 7 \\
\% \operatorname{Exp}\end{array}$} & \multirow{2}{*}{$\begin{array}{c}\text { Day } 9 \\
\% \text { Hatch }\end{array}$} \\
\hline & & $\%$ Cleaved & $\% 5-8 c$ & $\% M+B$ & $\% \mathrm{~B}$ & & \\
\hline TRR & 521 & $71.9 \pm 0.6^{b}$ & $46.7 \pm 0.4^{\mathrm{a}}$ & $42.1 \pm 0.7^{\mathrm{a}}$ & $19.7 \pm 0.7^{\mathrm{a}}$ & $30.2 \pm 0.7^{\mathrm{a}}$ & $22.7 \pm 0.4^{\mathrm{a}}$ \\
\hline F-T & 501 & $76.1 \pm 0.6^{\mathrm{a}}$ & $46.2 \pm 0.8^{\mathrm{a}}$ & $32.5 \pm 0.9^{b}$ & $13.4 \pm 0.3^{c}$ & $26.5 \pm 0.4^{b}$ & $19.7 \pm 0.5^{\mathrm{b}}$ \\
\hline LYO & 522 & $71.1 \pm 0.4^{\mathrm{b}}$ & $42.3 \pm 1.1^{\mathrm{b}}$ & $33.9 \pm 0.6^{\mathrm{b}}$ & $17.2 \pm 0.7^{\mathrm{b}}$ & $25.9 \pm 0.6^{\mathrm{b}}$ & $18.1 \pm 0.3^{\mathrm{c}}$ \\
\hline
\end{tabular}

M: morulae; B: blastocysts; Exp: Expanded blastocysts; Hatch: Hatched blastocysts; data (6 replicates) are LSM \pm SE. Different superscripts within columns differ statistically significantly $\left({ }^{\mathrm{a}, \mathrm{b}, \mathrm{c}} \mathrm{P}<\right.$ 0.05). Cleavage rates are referred to the zygotes cultured. Embryo development from Day 3 to Day 9 is referred to cleaved embryos 


\section{Discussion}

We have shown that, in our conditions, SOF-T3 increases the Day-7 blastocyst expansion rates, while no differences in hatching rates were obtained by increasing the BSA concentrations. On the other hand, addition of FCS to SOFaaci at $48 \mathrm{~h}$ and at $72 \mathrm{~h}$ PI allowed us to obtain better Day- 6 embryo development rates than when FCS was added at 18 or $96 \mathrm{~h}$ PI. However, hatching rates were improved when serum was added at $72 \mathrm{~h}$ PI. Finally, both refrigeration and lyophilisation appeared as cryopreservation procedures producing a significant loss of the ability of CM to support embryo development, related to the control fresh culture medium.

Embryo culture conditions vary widely. In particular, the composition of culture medium has not been established for many mammalian species yet. Although the intrinsic quality of the oocyte is considered to be the principal factor affecting the production of blastocysts (Rizos et al., 2002), it has been stated that the culture conditions determine the quality of in vitro produced embryos (Lonergan, 2007). As proposed by Leese et al. (2008), CM should promote embryo metabolism by providing a combination of substrates which lead them to adopt a metabolic pattern close to that exhibited in the female tract. Such a strategy is also likely to lead embryos to utilise endogenous nutrients. The need to maintain early embryos in systems designed to minimise stress has also been stated by Lane and Gardner (2005).

Many media used for embryo development contain serum or BSA as protein source. A nutritional role is attributed to BSA, a relatively impure compound with contaminants such as citrate (Kane, 1991; Gray et al., 1992) or endotoxins (Dumoulin et al., 1991); some commercially available preparations may even contain growth factors. Consequently, differences among batches of BSA may have a large influence on the results of embryo culture. Already in the early 1990s, Gray et al. (1992) and Keskintepe et al. (1995) demonstrated the embryotrophic effects of sodium citrate by stimulating the synthesis of amino acids and by chelating metal ions. This property is crucial for embryo development and for compaction and formation of the blastocoele (Gray et al., 1992). Some authors have observed that the absence of BSA from the culture medium significantly reduces embryo development (Carolan et al., 1995). The replacement of BSA with synthetic macromolecules, such as polyvinyl alcohol, allowed to obtain blastocysts with relative success (Takahashi and First, 1992). By increasing BSA concentration from 3 to $8 \mathrm{~g} / \mathrm{L}$, we did not observe any improvement in embryo developmental ability. In a recent study (Gómez et al., 2008), parallel to increasing the BSA concentrations up to $20 \mathrm{~g} / \mathrm{L}$, embryo development rates decreased in relation to the control group $(6 \mathrm{~g} / \mathrm{L})$ although embryo quality in terms of resistance to the vitrification procedures improved. 
Experiment 2 showed that SOFaaci is a suitable medium for producing bovine embryos in vitro. Our data agree with the results reported by Holm et al. (1999), who stated that this culture system accelerated the formation of blastocysts and also led to cell proliferation, evidencing that this medium improves culture conditions. Moreover, our results improved the developmental rates (cleavage and blastocyst rates) reported by Takahashi and First (1992) in SOF-T and by Carolan et al. (1995) in SOF with $10 \%$ of FCS, also added at $42 \mathrm{~h}$ postFIV.

Although the role of serum is not completely defined (for a review see Thompson et al., 2007), it has been demonstrated that serum has a biphasic effect inhibiting early cleavage divisions and accelerating the development of morulae and blastocysts compared with those produced in its absence (Bavister et al., 1992; Gordon, 1994; Pinyopummintr and Bavister, 1994; Van Langendonckt et al., 1997; Lonergan et al., 1999). Also, Holm et al. (1999) showed that the addition of trisodium citrate to a SOF medium containing PVA, amino acids and myoinositol increased the developmental rates of bovine blastocysts.

As previously stated, and although a higher development rate to the blastocyst stage is obtained from media supplemented with serum, the inclusion of serum in the CM cause some alterations in the embryos (Pinyopummintr and Bavister, 1994; Van Langendonckt et al., 1997; Holm et al., 1999; Abe et al., 2002; Wrenzycki et al., 2004; Gómez et al., 2008), making them substantially different from embryos obtained in vivo (Lonergan, 2007). Related to this, partial in vivo culture improved the Day- 8 blastocyst appearance, and also the embryo quality in terms of cryosurvival (Havlicek et al., 2009). Considering the sanitary implications of using animal-derived sera or proteins, a trend to use more defined proteins, such as BSA, human serum albumin and synthetic serum preparations instead of undefined natural serum preparations has been promoted (Sagirkaya et al., 2006).

The results obtained in the second experiment also confirm the abovementioned biphasic effect of the serum, previously stated by several researchers (Bavister et al., 1992; Gordon, 1994; Pinyopummintr and Bavister, 1994; Van Langendonckt et al., 1997; Lonergan et al., 1999) and support the idea that during the earliest divisions, embryos prefer a simple medium to sustain development. Thus, we obtained the lowest Day-3 developmental data after the addition of serum at $18 \mathrm{~h}$ PI, while the best percentages of embryo division were attained when the serum was added $72 \mathrm{~h}$ PI. Duque et al. (2003) also showed that the concentration of protein supplementation and the timing of its inclusion in the culture medium strongly affect embryo development.

The use of frozen-thawed and lyophilised culture medium significantly decreased developmental rates related to the control group (fresh SOFaaci), indicating that both procedures used for preserving CM affect its properties and ability to support embryo development. However, and taking account this fact, it has 
to be noted that non-negligible Day-7 expansion rates were obtained after embryo culture in frozen-thawed and lyophilised medium. This fact could be interesting in terms of compensating the variations among replicates, due to the weekly preparation of fresh CM.

Lyophilisation reduces quality losses due to chemical reactions, and also prevents enzymatic and non-enzymatic degradation processes (Liao et al., 2002). However, it must be considered that the low humidity levels achieved during the drying procedure can alter the lipid oxidation processes. To counteract these reactions, lyophilised products should be stored in non-oxygen-permeable receptacles. Lyophilisation does not promote protein denaturalisation (Salnikova et al., 2008), due the low temperature used during the whole procedure, making this preservation system interesting for the purposes of CM storage. However, it has been previously demonstrated that the qualitative and quantitative composition of a formulation has deep implications on the design of a lyophilisation programme as well as on the characteristics of the freeze-dried product (Lueckel et al., 1998).

Some animal sera and serum replacements are provided in lyophilised form by many laboratories for use in in vitro procedures. Many additives such as BSA, and most of the reagents used for CM preparation are routinely preserved by lyophilisation. However, to the best of our knowledge, no studies have yet been published that analysed the effect of preserving the whole CM on long-time storage for in vitro culture in cattle.

In conclusion, SOFaaci supplemented with FCS at $72 \mathrm{~h}$ PI improves the hatching rates of in vitro produced bovine embryos. Long-term preservation of this medium by freezing or lyophilisation techniques impairs the ability of the CM to support embryo development up to the blastocyst stage and hatching, although non-negligible Day-7 expansion rates are obtained in relation to the control group (fresh SOFaaci). Further studies are needed to elucidate the role of preservation procedures in the in vitro production systems.

\section{Acknowledgement}

The grant support by Junta de Castilla y León, Spain, is gratefully acknowledged.

\section{References}

Abe, H., Yamashita, S., Satoh, T. and Hoshi, H. (2002): Accumulation of cytoplasmic lipid droplets in bovine embryos and cryotolerance of embryos developed in different culture systems using serum-free or serum-containing media. Mol. Reprod. Dev. 61, 57-66.

Bavister, B. D., Rose-Hellekany, T. A. and Pinyopummintr, T. (1992): Development of in vitro matured/in vitro fertilized bovine embryos into morulae and blastocysts in defined culture media. Theriogenology 37, 127-146. 
Carolan, C., Lonergan, P., Van Langendonckt, A. and Mermillod, P. (1995): Factors affecting bovine embryo development in synthetic oviduct fluid following oocyte maturation and fertilization in vitro. Theriogenology $\mathbf{4 3}, 1115-1128$.

de la Varga, S., Díez, C., Alvarez, E., Fernández, A., Fernández, L. and Carbajo, M. (2005): Freezing or lyophilization as tools for the long-term storage of a bovine embryo culture medium. Reprod. Domest. Anim. 40, 384 (Abstr).

Dumoulin, J. C., Meheere, P. P., Evers, J. L., Kleukers, A. P., Pieters, M. H., Bras, M. and Geraedts, J. P. (1991): The effects of endotoxins on gametes and preimplantation embryos cultured in vitro. Hum. Reprod. 6, 730-734.

Duque, P., Gómez, E., Díaz, E., Facal, N., Hidalgo, C. and Díez, C. (2003): Use of two replacements of serum during bovine embryo culture in vitro. Theriogenology 59, 889-899.

Gómez, E., Rodríguez, A., Muñoz, M., Caamaño, J. N., Hidalgo, C. O. and Moran, E. (2008): Serum free embryo culture medium improves in vitro survival of bovine blastocysts to vitrification. Theriogenology 69, 1013-1021.

Gordon, I. (1994): Laboratory production of cattle embryos. In: Gordon, I. (ed.) Biotechnology in Agriculture. CAB International, Wallingford. pp. 77-257.

Gray, C. W., Morgan, P. M. and Kane, M. T. (1992): Purification of embryotrophic factor from commercial bovine serum albumin and its identification as citrate. J. Reprod. Fert. 94, 471-480.

Havlicek, V., Kuzmany, A., Cseh, S., Brem, G. and Besenfelder, U. (2009): The effect of longterm in vivo culture in bovine oviduct and uterus on the development and cryo-tolerance of in vitro produced bovine embryos. Reprod. Domest. Anim. 2009 Mar 28. [Epub ahead of print, PMID: 19416481]

Holm, P., Booth, P. J., Schmidt, M. H., Greve, T. and Callesen, H. (1999): High bovine blastocyst development in a static in vitro production system using SOFaa medium supplemented with sodium citrate and myo-inositol with or without serum-proteins. Theriogenology 52, $683-700$.

Kane, M. T. (1991): Control of growth in preimplantation embryos. Irish J. Med. Sci. 160, 17-22.

Keskintepe, L., Burnley, C. A. and Brackett, B. G. (1995): Production of viable bovine blastocysts in defined in vitro culture conditions. Biol. Reprod. 52, 1410-1417.

Lane, M. and Gardner, D. K. (2005): Understanding cellular disruptions during early embryo development that perturb viability and fetal development. Reprod. Fert. Dev. 17, 371-378.

Leese, H. J., Baumann, Ch. G., Brison, D. R., McEvoy, T. G. and Sturmey, R. G. (2008): Metabolism of the viable mammalian embryo: quietness revisited. Mol. Hum. Reprod. 14, 667-672.

Liao, Y. H., Browin, M. B., Auader, A. and Martin, G. P. (2002): Protective mechanism of stabilizing excipients against dehydration in the freeze-drying of proteins. Pharm. Res. 19, 1854-1861.

Lonergan, P. (2007): State-of-the-art embryo technologies in cattle. Soc. Reprod. Fertil. Suppl. 64, $315-325$.

Lonergan, P., O’Kearney-Flynn, M. and Boland, M. P. (1999): Effect of protein supplementation and presence of an antioxidant on the development of bovine zygotes in synthetic oviduct fluid medium under high or low oxygen tension. Theriogenology 51, 1565-1576.

Lonergan, P., Rizos, D., Gutiérrez-Adán, A., Fair, T. and Boland, M. P. (2003): Oocyte and embryo quality: effect of origin, culture conditions and gene expression patterns. Reprod. Domest. Anim. 38, 259-267.

Lueckel, B., Bodmer, D., Helk, B. and Leuenberger, H. (1998): Formulations of sugars with amino acids or mannitol - influence of concentration ratio on the properties of the freezeconcentrate and the lyophilizate. Pharm. Dev. Technol. 3, 325-336.

Parrish, J. J., Susko-Parrish, J. L., Leibfried-Rutledge, M. L., Critser, E. S., Eyestone, W. H. and First, N. L. (1986): Bovine in vitro fertilization with frozen-thawed semen. Theriogenology 25, 591-600.

Pinyopummintr, T. and Bavister, B. D. (1994): Development of bovine embryos in a cell-free culture medium: Effects of type of serum, timing of its inclusion and heat inactivation. Theriogenology 41, 1241-1249. 
Prescott, L. M., Harley, J. P. and Klein, D. A. (2009): Metabolism: Energy, Enzymes and Regulation (in Spanish). In: Willey, Joanne M. (ed.) Microbiología. 7th edition. McGraw-Hill Interamericana de Espana, Madrid. pp. 163-183.

Rizos, D., Lonergan, P., Ward, F., Duffy, P. and Boland, M. P. (2002): Consequences of bovine oocyte maturation, fertilization or early embryo development in vitro versus in vivo: implications for blastocyst yield and blastocyst quality. Mol. Reprod. Dev. 61, 234-248.

Sagirkaya, H., Misirlioglu, M., Kaya, A., First, N. L., Parrish, J. J. and Memili, E. (2006): Developmental and molecular correlates of bovine preimplantation embryos. Reproduction 131, 895-904.

Salnikova, M. S., Middaugh, C. R. and Rytting, J. H. (2008): Stability of lyophilized human growth hormone. Int. J. Pharm. 358, 108-113.

Takahashi, Y. and First, N. L. (1992): In vitro development of bovine one-cell embryos: influence of glucose, lactate, pyruvate, amino acids and vitamins. Theriogenology 37, 963-978.

Thompson, J. G., Mitchell, M. and Kind, K. L. (2007): Embryo culture and long-term consequences. Reprod. Fertil. Dev. 19, 43-52.

Van Langendonckt, A., Donnay, I., Schuurbiers, N., Auquier, P., Carolan, C., Massip, A. and Dessy, F. (1997): Effects of supplementation with fetal calf serum on development of bovine embryos in synthetic oviduct fluid medium. J. Reprod. Fertil. 109, 87-93.

Wrenzycki, C., Herrmann, D., Lucas-Hahn, A., Lemme, E., Korsawe, K. and Niemann, H. (2004): Gene expression patterns in in vitro-produced and somatic nuclear transfer-derived preimplantation bovine embryos: relationship to the large offspring syndrome? Anim. Reprod. Sci. 82-83, 593-603. 